The Canadian Mineralogist

Vol. 43, pp. 1393-1400 (2005)

\title{
CALCIOPETERSITE FROM DOMAŠOV NAD BYSTŘICÍ, NORTHERN MORAVIA, CZECH REPUBLIC, A NEW MINERAL SPECIES OF THE MIXITE GROUP
}

\author{
JIř́í SEJKORA ${ }^{\S}$ \\ Department of Mineralogy and Petrology, National Museum, Václavské nám. 68, CZ-115 79 Praha 1, Czech Republic \\ PAVEL NOVOTNÝ \\ Department of Natural History, Museum of National History and Arts, nám. Republiky 5, \\ CZ-771 73 Olomouc, Czech Republic \\ MiLAN NOVÁK \\ Institute of Geological Sciences, Masaryk University, Kotlárská 2, CZ-611 37 Brno, Czech Republic \\ VLADIMÍR ŠREIN \\ Institute of Rock Structures and Mechanics, Academy of Science of Czech Republic, \\ V Holešovičkách 41, CZ-182 09 Praha 8, Czech Republic \\ PETER BERLEPSCH \\ Laboratorium für Chemiche und Mineralogische Kristallographie, Universität Bern, \\ Freiestrasse 3, CH-3012 Bern, Switzerland
}

\begin{abstract}
Calciopetersite, ideally $\mathrm{CaCu}_{6}\left[\left(\mathrm{PO}_{4}\right)_{2}\left(\mathrm{PO}_{3} \mathrm{OH}\right)(\mathrm{OH})_{6}\right] \cdot 3 \mathrm{H}_{2} \mathrm{O}$, occurs in cavities in quartz veins at an abandoned quarry near Domašov nad Bystřicí, $20 \mathrm{~km}$ northeast of Olomouc, northern Moravia, Czech Republic. It forms translucent to transparent minute acicular crystals, up to $0.4 \mathrm{~mm}$ in length and 5-20 $\mu \mathrm{m}$ in width, with a hexagonal outline, clustered in fine radiating sprays (up to $0.1 \times 0.5 \mathrm{~mm}$ ). It is soft and brittle with an uneven fracture, but the hardness and density could not measured; no cleavage was observed. It has an olive green color, light olive green streak and vitreous luster. No fluorescence was observed in ultraviolet light. It originated by weathering of chalcopyrite and other copper sulfides and is associated with chrysocolla, the Ce-dominant analogue of petersite-(Y), malachite, allophane, goethite, lepidocrocite, chalcopyrite, pyrite, covellite, chalcocite and quartz. The name calciopetersite denotes that it is the Ca-dominant analogue of petersite-(Y). Calciopetersite is hexagonal, space group $P 6_{3} / m$ inferred from the isotypic agardite-(Y) and mixite, $a$ 13.284(4), c 5.902(4) $\AA, V$ 902.0(6) $\AA^{3}, Z=2$, and $D_{\text {calc }}$ $3.332 \mathrm{~g} / \mathrm{cm}^{3}$. The strongest eight lines in the powder-diffraction pattern $[d$ in $\AA(I)(h k l)]$ are: $11.51(100)(100), 4.346(88)(210)$, 4.140(46)(201), 3.837(38)(300), 3.321(44)(220), 2.888(53)(221), 2.877(37)(400), and 2.510(37)(140). Calciopetersite is uniaxial positive, with indices of refraction $\omega 1.674(5)$ and $\varepsilon>1.739(\sim 1.75)$ in Na light $(590 \mathrm{~nm})$, and dichroic: light green with yellowish tint $(\mathrm{O})$ and green $(\mathrm{E})$ with $\varepsilon>\omega$. Chemical analyses yielded the average composition $\mathrm{K}_{2} \mathrm{O} 0.09, \mathrm{CaO} 4.39, \mathrm{CuO} 51.25, \mathrm{Y}_{2} \mathrm{O}_{3}$ 1.61, $\mathrm{La}_{2} \mathrm{O}_{3} 0.64, \mathrm{Ce}_{2} \mathrm{O}_{3} 1.98, \mathrm{Pr}_{2} \mathrm{O}_{3} 0.25, \mathrm{Nd}_{2} \mathrm{O}_{3}, 1.40, \mathrm{Dy}_{2} \mathrm{O}_{3} 0.33, \mathrm{Yb}_{2} \mathrm{O}_{3} 0.21, \mathrm{Bi}_{2} \mathrm{O}_{3} 0.09, \mathrm{SiO}_{2} 0.52, \mathrm{P}_{2} \mathrm{O}_{5} 20.98, \mathrm{As}_{2} \mathrm{O}_{5}$ 2.70, $\mathrm{H}_{2} \mathrm{O}$ (12.45), total (98.89) wt.\%, corresponding to $\left(\mathrm{Ca}_{0.58} \mathrm{Y}_{0.13} \mathrm{Ce}_{0.11} \mathrm{Nd}_{0.08} \mathrm{La}_{0.04} \mathrm{~K}_{0.02} \mathrm{Dy}_{0.02} \mathrm{Pr}_{0.01} \mathrm{Yb}_{0.01}\right)_{\Sigma 1.00}\left(\mathrm{Cu}_{5.90} \mathrm{Ca}_{0.14}\right)_{\Sigma 6.04}$ $\left[\left(\mathrm{PO}_{4}\right)_{2.06}\left(\mathrm{PO}_{3} \mathrm{OH}\right)_{0.65}\left(\mathrm{AsO}_{4}\right)_{0.22}\left(\mathrm{SiO}_{4}\right)_{0.22}(\mathrm{OH})_{6}\right]^{\bullet} 3.00 \mathrm{H}_{2} \mathrm{O}$ on the basis of 21 atoms per formula unit. The ideal formula $\mathrm{CaCu}$ ${ }_{6}\left[\left(\mathrm{PO}_{4}\right)\left(\mathrm{PO}_{3} \mathrm{OH}\right)(\mathrm{OH})_{6}\right] \cdot 3 \mathrm{H}_{2} \mathrm{O}$ requires $\mathrm{CaO} 6.50, \mathrm{CuO} 55.28, \mathrm{P}_{2} \mathrm{O}_{5} 24.66, \mathrm{H}_{2} \mathrm{O}$ 13.57, total 100.00 wt.\%. The Gladstone-Dale compatibility index, calculated from incomplete optical data, is poor $(-0.080)$. We provide a tentative interpretation of the infrared-absorption spectrum of calciopetersite.
\end{abstract}

Keywords: calciopetersite, new mineral species, X-ray powder diffraction, electron-microprobe data, infrared spectroscopy, mixite group, Domašov nad Bystřicí, Czech Republic.

\$E-mail address: jiri.sejkora@nm.cz 


\section{SOMMAIRE}

On trouve la calciopetersite, dont la formule idéale serait $\mathrm{CaCu}_{6}\left[\left(\mathrm{PO}_{4}\right)_{2}\left(\mathrm{PO}_{3} \mathrm{OH}\right)(\mathrm{OH})_{6}\right] \cdot 3 \mathrm{H}_{2} \mathrm{O}$, dans les cavités de veines de quartz dans une carrière abandonnée près de Domašov nad Bystřicí, à $20 \mathrm{~km}$ au nord-est de Olomouc, partie nord de la Moravie, en République Tchèque. Elle se présente en infimes cristaux aciculaires translucides à transparents atteignant une longueur de $0.4 \mathrm{~mm}$ et entre 5 et $20 \mu \mathrm{m}$ de diamètre, avec une section hexagonale, regroupés en amas radiaires atteignant $0.1 \times 0.5 \mathrm{~mm}$. C'est un minéral mou et cassant, avec une fracture inégale, mais nous n'avons pas pu en établir la dureté ou la densité. Aucun clivage n'est évident. Sa couleur est vert olive, et sa rayure, vert olive pâle; l'éclat est vitreux. Aucune fluorescence n'a été observée en lumière ultraviolette. On attribue la calciopetersite à la météorisation de la chalcopyrite et autres sulfures de cuivre; elle est associée au chrysocolle, l'analogue à dominance de Ce de la petersite-(Y), et à malachite, allophane, goethite, lépidocrocite, chalcopyrite, pyrite, covellite, chalcocite et quartz. Le nom calciopetersite rappelle la dominance de Ca dans un analogue de la petersite-(Y). La calciopetersite est hexagonale, groupe spatial $P 6_{3} / m$, déduit à partir de l'agardite-(Y) et la mixite, phases isotypiques, $a$ 13.284(4), $c$ 5.902(4) $\AA, V$ 902.0(6) $\AA^{3}, Z=2$, et $D_{\text {calc }} 3.332 \mathrm{~g} / \mathrm{cm}^{3}$. Les huit raies les plus intenses du spectre de diffraction $X$, méthode des poudres $[d$ en $\AA(I)(h k l)]$ sont: 11.51(100)(100), 4.346(88)(210), 4.140(46)(201), 3.837(38)(300), 3.321(44)(220), 2.888(53)(221), 2.877(37)(400), et 2.510(37)(140). La calciopetersite est uniaxe positive, avec les indices de refraction $\omega$ 1.674(5) et $\varepsilon>1.739(\sim 1.75)$ en lumière $\mathrm{Na}(590 \mathrm{~nm})$, et dichroïque, de vert pâle avec une teinte jaunâtre $(\mathrm{O})$ à vert (E), avec $\varepsilon>\omega$. Les analyses chimiques ont donné, en moyenne, $\mathrm{K}_{2} \mathrm{O} 0.09, \mathrm{CaO} 4.39, \mathrm{CuO} 51.25, \mathrm{Y}_{2} \mathrm{O}_{3} 1.61, \mathrm{La}_{2} \mathrm{O}_{3} 0.64$, $\mathrm{Ce}_{2} \mathrm{O}_{3}$ 1.98, $\mathrm{Pr}_{2} \mathrm{O}_{3} 0.25, \mathrm{Nd}_{2} \mathrm{O}_{3}, 1.40, \mathrm{Dy}_{2} \mathrm{O}_{3} 0.33, \mathrm{Yb}_{2} \mathrm{O}_{3} 0.21, \mathrm{Bi}_{2} \mathrm{O}_{3} 0.09, \mathrm{SiO}_{2} 0.52, \mathrm{P}_{2} \mathrm{O}_{5} 20.98, \mathrm{As}_{2} \mathrm{O}_{5} 2.70, \mathrm{H}_{2} \mathrm{O}$ (12.45), pour un total de (98.89)\% (poids), ce qui correspond à $\left(\mathrm{Ca}_{0.58} \mathrm{Y}_{0.13} \mathrm{Ce}_{0.11} \mathrm{Nd}_{0.08} \mathrm{La}_{0.04} \mathrm{~K}_{0.02} \mathrm{Dy}_{0.02} \mathrm{Pr}_{0.01} \mathrm{Yb}_{0.01}\right)_{\Sigma 1.00}\left(\mathrm{Cu}_{5.90} \mathrm{Ca}_{0.14}\right)_{\Sigma 6.04}$ $\left[\left(\mathrm{PO}_{4}\right)_{2.06}\left(\mathrm{PO}_{3} \mathrm{OH}\right)_{0.65}\left(\mathrm{AsO}_{4}\right)_{0.22}\left(\mathrm{SiO}_{4}\right)_{0.22}(\mathrm{OH})_{6}\right] \cdot 3.00 \mathrm{H}_{2} \mathrm{O}$ sur une base de 21 atomes par formule unitaire. La formule idéale $\mathrm{CaCu}_{6}\left[\left(\mathrm{PO}_{4}\right)\left(\mathrm{PO}_{3} \mathrm{OH}\right)(\mathrm{OH})_{6}\right] \cdot 3 \mathrm{H}_{2} \mathrm{O}$ requiert $\mathrm{CaO}$ 6.50, CuO 55.28, $\mathrm{P}_{2} \mathrm{O}_{5} 24.66, \mathrm{H}_{2} \mathrm{O}$ 13.57, total 100.00\%. L'indice de compatibilité de Gladstone et Dale, calculé en utilisant des données optiques incomplètes, est pauvre $(-0.080)$. Nous interprétons de façon préliminaire le spectre d'absorption infrarouge de la calciopetersite.

(Traduit par la Rédaction)

Mots-clés: calciopetersite, nouvelle espèce minérale, diffraction X sur poudre, données de microsonde électronique, spectroscopie infrarouge, groupe de la mixite, Domašov nad Bystřicí, République Tchèque.

\section{INTRODUCTION}

Minerals of the mixite group have the general formula $\mathrm{MCu}_{6}\left(\mathrm{XO}_{4}\right)_{3}(\mathrm{OH})_{6} \cdot 3 \mathrm{H}_{2} \mathrm{O}$. Cations such as $\mathrm{Al}$, $\mathrm{Bi}^{3+}, \mathrm{Ca}, \mathrm{Y}^{3+}$ and the rare-earth elements $\left(\mathrm{REE}^{3+}\right)$ are found to occupy the octahedrally coordinated $M$ site; up to now, only As and $\mathrm{P}$ have been found in significant amounts at $X$, the tetrahedral site. We describe in this paper the physical properties and chemical composition of calciopetersite, a newly discovered member of the mixite group, from Domašov nad Bystřicí, northern Moravia, Czech Republic.

\section{BACKGROUND INFORMATION}

Minerals of the mixite group have been classified on the basis of the occupancy of the $M$ and $X$ sites: mixite [Bi; As], agardite-(Y) [Y; As], goudeyite [Al; As], petersite-(Y) [Y; P], zálesíite [Ca; As], agardite(La) [La, As], approved mineral 2003-030 [Ce, As], approved mineral 2003-031a [Pb, As], and the new mineral species calciopetersite, described here $[\mathrm{Ca} ; \mathrm{P}]$. The names "agardite-(Nd)", "agardite-(Dy)", "petersite(Nd)", "petersite-(Ca)" (Walenta 2003, Walenta \& Theye 2004) and "agardite-(Ca)" were occasionally used, but these minerals and their names have not been approved by the Commission of New Minerals and Mineral Names (CNMMN) of the International Mineralogical Association (IMA).
Compositional variation in the proportion of the major cations, especially the substitution $\mathrm{P} \rightarrow \mathrm{As}$ in mixite (Schrauf 1880, Sejkora \& Šrein 1996), As $\rightarrow P$ in petersite-(Y) (Peacor \& Dunn 1982), and the REEs in agardite-(Y), agardite-(Ce) and agardite-(La), was documented on the intermediate members of this group at some occurrences in Sardinia, Italy (Olmi et al. 1991). Subordinate contents of Ca were found in many members of the mixite group by Olmi et al. (1991). Furthermore, Dietrich et al. (1969) described 14 mol.\% $\mathrm{Ca}$ at the $M$ site in mixite and $25 \mathrm{~mol} . \%$ in agardite-(Y), and Peacor \& Dunn (1982) found $40 \mathrm{~mol} . \% \mathrm{Ca}$ at the $M$ site in petersite-(Y), respectively. On the other hand, $\mathrm{Ca}$ in goudeyite is considered to occupy the $\mathrm{Cu}$ site (Wise 1978). Aruga \& Nakai (1985) described the crystal structure of Ca-rich agardite-(Y) (44 mol.\% of Ca at the $M$ site) and assumed that substitution of a trivalent cation $\left(\mathrm{Bi}^{3+}\right.$ or $\left.\mathrm{REE}^{3+}\right)$ at the $M$ site by divalent $\mathrm{Ca}^{2+}$ cation is charge-balanced by a concomitant substitution of $\mathrm{OH}^{-}$for $\mathrm{O}^{2-}$ at the $\mathrm{O}(3)$ site in the crystal structure (attributed to a $\mathrm{HAsO}_{4}$ or $\mathrm{AsO}_{3} \mathrm{OH}$ group). Zálesíite, $\mathrm{CaCu}_{6}\left[\left(\mathrm{AsO}_{4}\right)\left(\mathrm{AsO}_{3} \mathrm{OH}\right)(\mathrm{OH})_{6}\right] \cdot 3 \mathrm{H}_{2} \mathrm{O}$, was described by Sejkora et al. (1999) as the first Ca-dominant member of the mixite group; however, the phase corresponding to zálesíite was described as agardite-(Ca) from Monte Cervandone (Italy), Vosges (France) and Black Forest (Germany) (Albertini 1994, Kolitsch 1997a, Walenta 1992). The new mineral species calciopetersite was incompletely described as the unnamed "Ca-dominant analogue of petersite-(Y)" from the mine Altväter samt 
Eschig near Sayda, Saxony by Kolitsch (1997b) or as "petersite-(Ca)" from Herrensegen mine near Schapbach, Black Forest by Walenta (1992, 2003).

Calciopetersite, the newly recognized hydrated hydroxophosphate of calcium and copper, has been approved by CNMMN of IMA (\#2001-004). The name is derived from its composition and relationship to petersite-(Y). The holotype specimen is deposited in the mineralogical collection of the Natural History Museum, National Museum, Prague, Czech Republic, under the number P1p-20/2000.

\section{OCCURRENCE AND DESCRIPTION}

Calciopetersite was found at a large abandoned quarry located about $1.5 \mathrm{~km}$ south of Domašov nad Bystřicí, $20 \mathrm{~km}$ northeast of Olomouc, northern Moravia, Czech Republic. The quarry was opened in the Lower Carboniferous (Upper Visean) graywackes, with layers of conglomerates and small intercalations of shales. Several generations of hydrothermal quartz, quartz-carbonate and calcite veins with a small amount of common sulfides (pyrite, chalcopyrite, sphalerite, galena; Zimák et al. in press) were found in the quarry. The steeply dipping hydrothermal vein in which the secondary calciopetersite was found is up to $10 \mathrm{~cm}$ thick and cuts greywacke and conglomerate. Quartz is a dominant gangue mineral besides subordinate carbonate (calcite + dolomite-ankerite), pyrite and chalcopyrite. Some minerals locally underwent a strong supergene alteration: chalcopyrite was largely replaced by chalcocite and covellite, and carbonate, by a porous mixture of goethite and lepidocrocite. Other secondary minerals associated with calciopetersite include chrysocolla, malachite, allophane and the unnamed Ce-analogue of petersite-(Y), with an ideal formula $(\mathrm{Ce}, \mathrm{REE}, \mathrm{Ca}) \mathrm{Cu}_{6}\left[\left(\mathrm{PO}_{4}\right)_{3}(\mathrm{OH})_{6}\right] \cdot 3 \mathrm{H}_{2} \mathrm{O}$, which is indistinguishable in hand specimen from calciopetersite. It occurs in cavities of the quartz vein closely associated with pale pink carbonate (calcite + dolomite-ankerite) veins with rare pyrite. Only a few samples of the very rare calciopetersite were found.

Calciopetersite forms translucent to transparent minute acicular crystals, attaining $0.4 \mathrm{~mm}$ in length and 5-20 $\mu \mathrm{m}$ in width, with a hexagonal outline, clustered in fine radiating sprays up to $0.1 \times 0.5 \mathrm{~mm}$ (Fig. 1). Crystals and their aggregates grow on quartz or host graywacke, and locally are coated by chrysocolla. Calciopetersite is soft and brittle with an uneven fracture, but the Mohs hardness was not determined owing to the size and character of aggregates; no cleavage was observed. The mineral is olive green, with a light olive green streak, a vitreous luster and pleochroism, from light green with yellowish tint $(\mathrm{O})$ to dark green (E). It is uniaxial positive, with $\omega 1.674(5)$ and $\varepsilon>$ $1.739(\sim 1.75)$ in Na light (590 nm, immersion liquids). No fluorescence at 254 and $366 \mathrm{~nm}$ of ultraviolet light was observed. The Gladstone-Dale compatibility index of calciopetersite, calculated from incomplete optical data, is poor $(-0.080)$, as are calculated compatibilities of other members of the mixite group $(-0.06$ to -0.10 ; Sejkora et al. 1999).

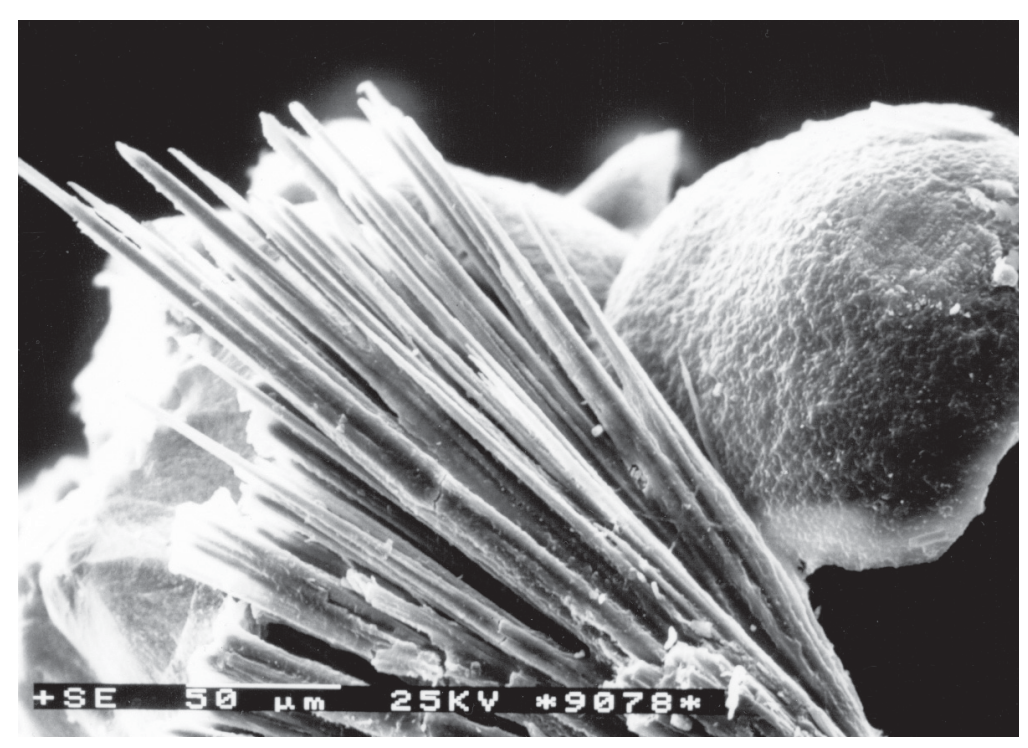

FIG. 1. Scanning electron photomicrograph of calciopetersite from Domašov nad Bystřicí, Czech Republic, in fine radiating sprays; note the hexagonal outline of crystals. Tesla BS 340, photo by J. Sejkora. 


\section{X-RAy Single-Crystal AND POWDER-DIFFRACTION DATA}

A pale greenish fragment of calciopetersite, about $0.01 \times 0.01 \times 0.05 \mathrm{~mm}^{3}$ in size, was measured on a Bruker AXS three-circle diffractometer (equipped with a CCD $1000 \mathrm{~K}$ area detector and a flat graphite monochromator) using $\mathrm{MoK} \alpha \mathrm{X}$-radiation emitted from a fine-focus sealed tube. The X-ray-diffraction data (734 reflections) were found to be of very poor quality, with a mean $I / \sigma_{I}=2.82$. For the structure refinement, the space group was set to $P 6_{3} / m$ in accordance with mixite and agardite-(Y) (Mereiter \& Preisinger 1986, Aruga \& Nakai 1985). The structure was refined with fixed isotropic thermal parameters for all atoms $\left(U_{\text {iso }}=\right.$ 0.01 ), and full occupancy was assumed for all atomic sites. Despite the poor data available, we can consider that the refined structure-model is isotypic with the one of Ca-rich agardite, reported by Aruga \& Nakai (1985). However, the structures can only be compared on a topological level; the poor quality of the underlying data does not allow a discussion of bond lengths and angles. The following unit-cell parameters were obtained: $a$ 13.3045(18), c 5.8711(8) ̊, V 900.0(4) $\AA^{3}$; attempts to solve the crystal structure from these data were not successful.

A hand-picked sample of calciopetersite was used to collect the X-ray powder-diffraction pattern using a Philips APD diffractometer operated in the step-scan mode. The diffraction lines are similar to the pattern of other phases of the mixite group. The unit-cell parameters were obtained from the powder X-ray-diffraction pattern (Table 1). It was collected in the range $3-66^{\circ}$ $2 \theta$ in the step-scan mode $\left(0.02^{\circ} / 15 \mathrm{~s}\right)$ with $\mathrm{CuK \alpha} \mathrm{X}$ radiation. Positions and intensities of reflections were calculated using the Pearson VII profile-shape function with the ZDS program package (Ondruš 1995). The measured pattern was indexed by analogy of isotypic

\begin{tabular}{|c|c|c|c|c|c|c|c|c|c|c|}
\hline $\mathrm{I}_{\mathrm{rel}}$ & $d_{\text {obs }}$ & $d_{\text {calc }}$ & $h$ & $k \quad l$ & $l$ & $\mathrm{I}_{\mathrm{rel}}$ & $d_{\mathrm{obs}}$ & $d_{\text {cale }}$ & $h$ & $k$ \\
\hline 100 & 11.51 & 11.50 & 1 & 00 & 0 & 37 & 2.510 & 2.510 & & 40 \\
\hline 88 & 4.346 & 4.348 & 2 & 10 & 0 & 13 & 2.4076 & 2.4094 & & 21 \\
\hline 46 & 4.140 & 4.119 & 2 & $\begin{array}{lll}0 & 1\end{array}$ & 1 & 20 & 2.2031 & 2.2060 & 2 & 22 \\
\hline 38 & 3.837 & 3.835 & 3 & $\begin{array}{lll}0 & 0\end{array}$ & 0 & 15 & 2.0654 & 2.0663 & & 50 \\
\hline 30 & 3.494 & 3.501 & 2 & 11 & 1 & 13 & 2.0601 & 2.0597 & 4 & 02 \\
\hline 44 & 3.321 & 3.321 & 2 & 20 & 0 & 31 & 1.9650 & 1.9673 & 3 & 22 \\
\hline \multirow[t]{2}{*}{35} & 3.184 & 3.191 & 1 & 30 & 0 & 28 & 1.8909 & 1.8913 & & 40 \\
\hline & & 3.191 & 3 & 10 & 0 & 17 & 1.6927 & 1.6927 & & 23 \\
\hline 53 & 2.888 & 2.894 & 2 & 21 & 1 & & & 1.6926 & 5 & 12 \\
\hline 37 & 2.877 & 2.876 & 4 & 00 & 0 & 22 & 1.6592 & 1.6605 & & 40 \\
\hline \multirow[t]{2}{*}{33} & 2.641 & 2.639 & 3 & 20 & 0 & 19 & 1.5939 & 1.5924 & 4 & 32 \\
\hline & & 2.639 & 2 & 30 & 0 & 18 & 1.4483 & 1.4472 & 4 & 42 \\
\hline 14 & 2.589 & 2.586 & 4 & 01 & 1 & 20 & 1.4390 & 1.4381 & 8 & 00 \\
\hline
\end{tabular}

Philips APD powder X-ray diffractometer, step-scan $0.02 \% 15 \mathrm{~s}$, CuKa radiation Positions and intensities of reflections were calculated using the Pearson VII profile shape function of the ZDS program package (Ondruš 1995). hexagonal $\left(P 6_{3} / m\right)$ Ca-rich agardite (Aruga \& Nakai 1985), mixite (Mereiter \& Preisinger 1986) and zálesíite (Sejkora et al. 1999). The unit-cell parameters of calciopetersite $[a$ 13.284(4) $\AA, c$ 5.902(4) $\AA, V$ 902.0(6) $\left.\AA^{3}, Z=2\right]$ were calculated by the least-squares refinement program of Burnham (1962). The density, 3.332 $\mathrm{g} / \mathrm{cm}^{3}$, is calculated for $Z=2$ and the chemical composition of calciopetersite.

\section{Chemical Composition}

Quantitative chemical analyses (Table 2) were carried out by means of a JEOL JXA-50A electron microprobe in wavelength mode (Geological Institute, Academy of Science of the Czech Republic, Prague, performed by A. Langrová and V. Šrein), operated at an acceleration potential $20 \mathrm{kV}$, a sample current $25 \mathrm{nA}$, and an electron beam size of $2 \mu \mathrm{m}$. We used the following standards: diopside $(\mathrm{Ca})$, libethenite $(\mathrm{Cu}$, $\mathrm{P})$, clinoclase (As), pucherite (Bi), K-feldspar (K) and synthetic glasses (REE) (Drake \& Weill 1972). The X-ray intensity of each element was measured three times with an exposure time of ten seconds. The data were corrected with the program based on the conventional ZAF methods of Duncumb \& Reed (1968) and Philibert (1963).

A direct determination of $\mathrm{H}_{2} \mathrm{O}$ was not possible because of small amount of available material. The $\mathrm{H}_{2} \mathrm{O}$ content was calculated from the empirical formula (on the basis $\mathrm{H}=12.65$ apfu derived from valence balance), and it is very close to the $\mathrm{H}_{2} \mathrm{O}$ content derived from the ideal formula. The analytical results calculated on the basis of $21(\mathrm{O}, \mathrm{OH})$ gave the following empirical formulae (average from eight spot-analyses): $\left(\mathrm{Ca}_{0.58}\right.$

\begin{tabular}{|c|c|c|c|}
\hline constituent & mean & range & $\begin{array}{l}\text { ideal } \\
\text { comp.*** }\end{array}$ \\
\hline $\mathrm{K}_{2} \mathrm{O}$ & 0.09 & $0.06-0.12$ & \\
\hline $\mathrm{CaO}$ & 4.39 & $3.72-4.80$ & 6.50 \\
\hline $\mathrm{CuO}$ & 51.25 & $50.66-51.70$ & 55.28 \\
\hline $\mathrm{Y}_{2} \mathrm{O}_{3}$ & 1.61 & $1.31-1.77$ & \\
\hline $\mathrm{La}_{2} \mathrm{O}_{3}$ & 0.64 & $0.36-0.85$ & \\
\hline $\mathrm{Ce}_{2} \mathrm{O}_{3}$ & 1.98 & $1.71-2.28$ & \\
\hline $\mathrm{Pr}_{2} \mathrm{O}_{3}$ & 0.25 & $0.13-0.42$ & \\
\hline $\mathrm{Nd}_{2} \mathrm{O}_{3}$ & 1.40 & $1.11-1.71$ & \\
\hline $\mathrm{Dy}_{2} \mathrm{O}_{3}$ & 0.33 & $0.22-0.51$ & \\
\hline $\mathrm{Yb}_{2} \mathrm{O}_{3}$ & 0.21 & $0.13-0.38$ & \\
\hline $\mathrm{Bi}_{2} \mathrm{O}_{3}$ & 0.09 & $0.03-0.23$ & \\
\hline $\mathrm{SiO}_{2}$ & 0.52 & $0.37-0.59$ & \\
\hline $\mathrm{P}_{2} \mathrm{O}_{5}$ & 20.98 & $19.70-22.38$ & 24.66 \\
\hline $\mathrm{As}_{2} \mathrm{O}_{5}$ & 2.70 & $2.08-3.89$ & \\
\hline $\mathrm{H}_{2} \mathrm{O}^{*}$ & $(12.45)$ & & 13.57 \\
\hline Total & $(98.89)$ & & 100.00 \\
\hline
\end{tabular}

JEOL JXA-50A electron microprobe, mean result and range of eight spot analyses. * calculated content of $\mathrm{H}_{2} \mathrm{O}$ on the base $\mathrm{H}=12.65 \mathrm{apfu}$ derived from valence balance with the empirical formula.

** ideal chemical composition calculated on the basis of the formula $\mathrm{CaCu}_{6}\left[\left(\mathrm{PO}_{4}\right)_{2}\left(\mathrm{PO} \mathrm{OH}_{3} \mathrm{OH}\right)(\mathrm{OH})_{6}\right] \cdot 3 \mathrm{H}_{2} \mathrm{O}$. 


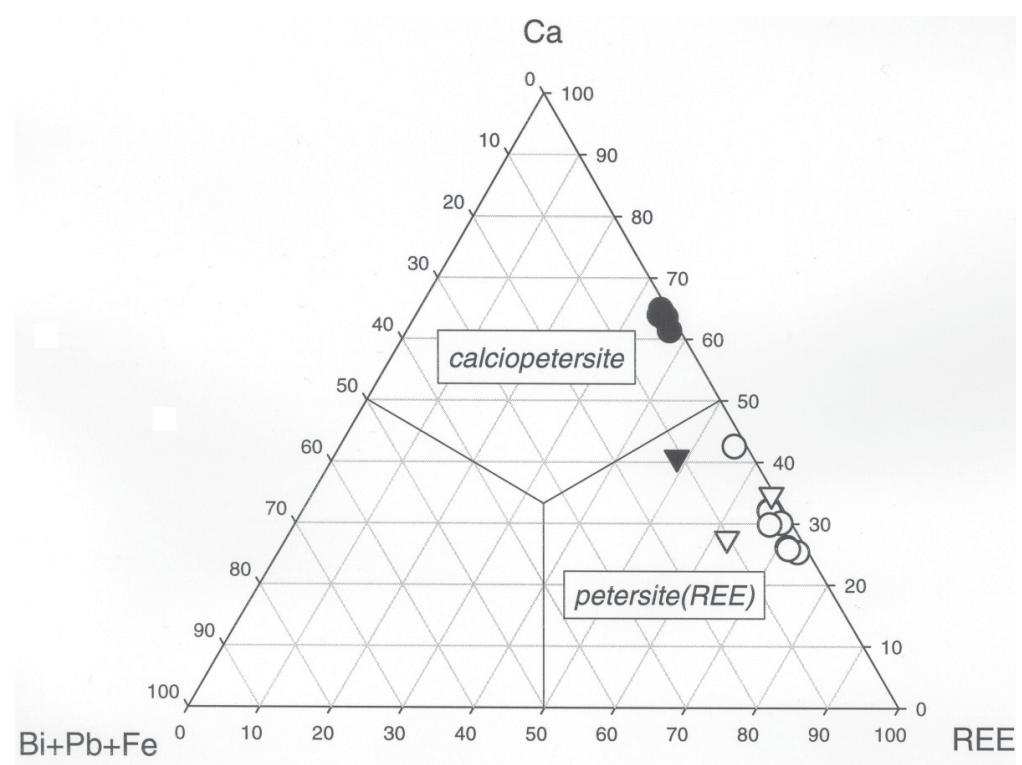

FIG. 2. Plot of $\mathrm{Ca}-\mathrm{REE}$ - other elements (at the $M$ site) in P-dominant members of the mixite group. : calciopetersite, Domašov (this paper), $\bigcirc$ : unnamed Ce-analogue of petersite-(Y), Domašov (this paper), $\boldsymbol{\nabla}$ petersite-(Y) (Peacor \& Dunn 1982), $\nabla\left(\mathrm{PO}_{4}\right)$ and REE-dominant members of the mixite group (Olmi et al. 1991).

$\left.\mathrm{Y}_{0.13} \mathrm{Ce}_{0.11} \mathrm{Nd}_{0.08} \mathrm{La}_{0.04} \mathrm{~K}_{0.02} \mathrm{Dy}_{0.02} \mathrm{Pr}_{0.01} \mathrm{Yb}_{0.01}\right)_{\Sigma 1.00}$ $\left(\mathrm{Cu}_{5.90} \mathrm{Ca}_{0.14}\right)_{\Sigma 6.04}\left[\left(\mathrm{PO}_{4}\right)_{2.06}\left(\mathrm{PO}_{3} \mathrm{OH}\right)_{0.65}\left(\mathrm{AsO}_{4}\right)_{0.22}\right.$ $\left.\left(\mathrm{SiO}_{4}\right)_{0.22}(\mathrm{OH})_{6}\right] \cdot 3.00 \mathrm{H}_{2} \mathrm{O}$.

Results of the individual spot-analyses of calciopetersite from Domašov nad Bystřicí as well as published analyses of P-dominant members of the mixite group are plotted in Figure 2. The substitution Ca for REE at the $M$ site is apparent and similar to that observed in As-dominant members of the mixite group (Olmi et al. 1991, Sejkora et al. 1999). The results lead to the ideal simplified formula $\mathrm{CaCu}_{6}\left[\left(\mathrm{PO}_{4}\right)_{2}\left(\mathrm{PO}_{3} \mathrm{OH}\right)(\mathrm{OH})_{6}\right] \bullet$ $3 \mathrm{H}_{2} \mathrm{O}$. In view of the existence of only one $X$ site (e.g., one As in the $X$ site described by Aruga \& Nakai $1985)$ and the disordered character of the substitution of $\mathrm{OH}^{-}$for $\mathrm{O}^{2-}$ at the $\mathrm{O}(3)$ site in the crystal structure of calciopetersite-type minerals, it seems better to assign a general formula $\mathrm{CaCu}_{6}\left[\mathrm{PO}_{3}\left(\mathrm{O}_{2 / 3}(\mathrm{OH})_{1 / 3}\right)\right]_{3}(\mathrm{OH})_{6} \bullet$ $3 \mathrm{H}_{2} \mathrm{O}$ to calciopetersite.

\section{INFRARED SPECTROSCOPY}

The infrared-absorption spectrum of calciopetersite (Fig. 3) was recorded with the Nicolet Magna IR microscope in the range $4000-600 \mathrm{~cm}^{-1}$ owing to a very small amount of sample available. The sample (less than $0.05 \mathrm{mg}$ ) was dispersed in a mixture with $\mathrm{KBr}$. A tentative assignment of individual bands in the spectrum (Table 3) is based on the findings of Keller (1971),
TABLE 3. INFRARED-ABSORPTION SPECTRUM OF CALCIOPETERSITE FROM DOMAŠOV NAD BYSTŘICÍ

\begin{tabular}{|c|c|c|c|}
\hline \multicolumn{3}{|c|}{ Wavenumbers $\left[\mathrm{cm}^{-1}\right]$} & Tentative assignment \\
\hline 3501 & $\mathrm{~m}$ & & \\
\hline 3390 & $\mathrm{~m}$ & br & $v \mathrm{OH}$-stretching vibrations \\
\hline 3326 & $\mathrm{mw}$ & sh & \\
\hline 1650 & $\mathrm{~m}$ & & \\
\hline 1635 & $\mathrm{~m}$ & sh & $\delta \mathrm{H}_{2} \mathrm{O}$-bending vibrations \\
\hline 1623 & $\mathrm{mw}$ & sh & \\
\hline 1498 & $\mathrm{vw}$ & & $\delta \mathrm{P}-\mathrm{OH}$ in-plane bending vibration \\
\hline 1379 & $\mathrm{vw}$ & & or overtones or combination bands \\
\hline 1108 & $\mathrm{~m}$ & sh & \\
\hline 1059 & vs & & \\
\hline 1032 & vs & & $v_{3}\left(\mathrm{PO}_{4}\right)^{3}$ antisymmetric stretching vibrations \\
\hline 1018 & $\mathrm{~s}$ & sh & \\
\hline 1001 & vs & & \\
\hline 982 & s & & \\
\hline 933 & $\mathrm{~m}$ & & $v_{1}\left(\mathrm{PO}_{4}\right)^{33}$ antisymmetric stretching vibrations \\
\hline 924 & $\mathrm{~m}$ & sh & \\
\hline 829 & $\mathrm{mw}$ & $\mathrm{sh}$ & \\
\hline 811 & $\mathrm{~m}$ & & $\delta \mathrm{P}-\mathrm{OH}$ out-of-plane bending vibrations \\
\hline 770 & $\mathrm{mw}$ & & or $\mathrm{H}_{2} \mathrm{O}$ libration modes (or both) \\
\hline 750 & $\mathrm{w}$ & sh & \\
\hline 722 & vw & sh & \\
\hline
\end{tabular}

Nicolet Magna IR microscope. Character of absorption maxima: sh: shoulder, $b$ broad. Intensity scale: vs: very strong, s: strong, m: medium, mw: medium weak, w: weak, vw: very weak. 


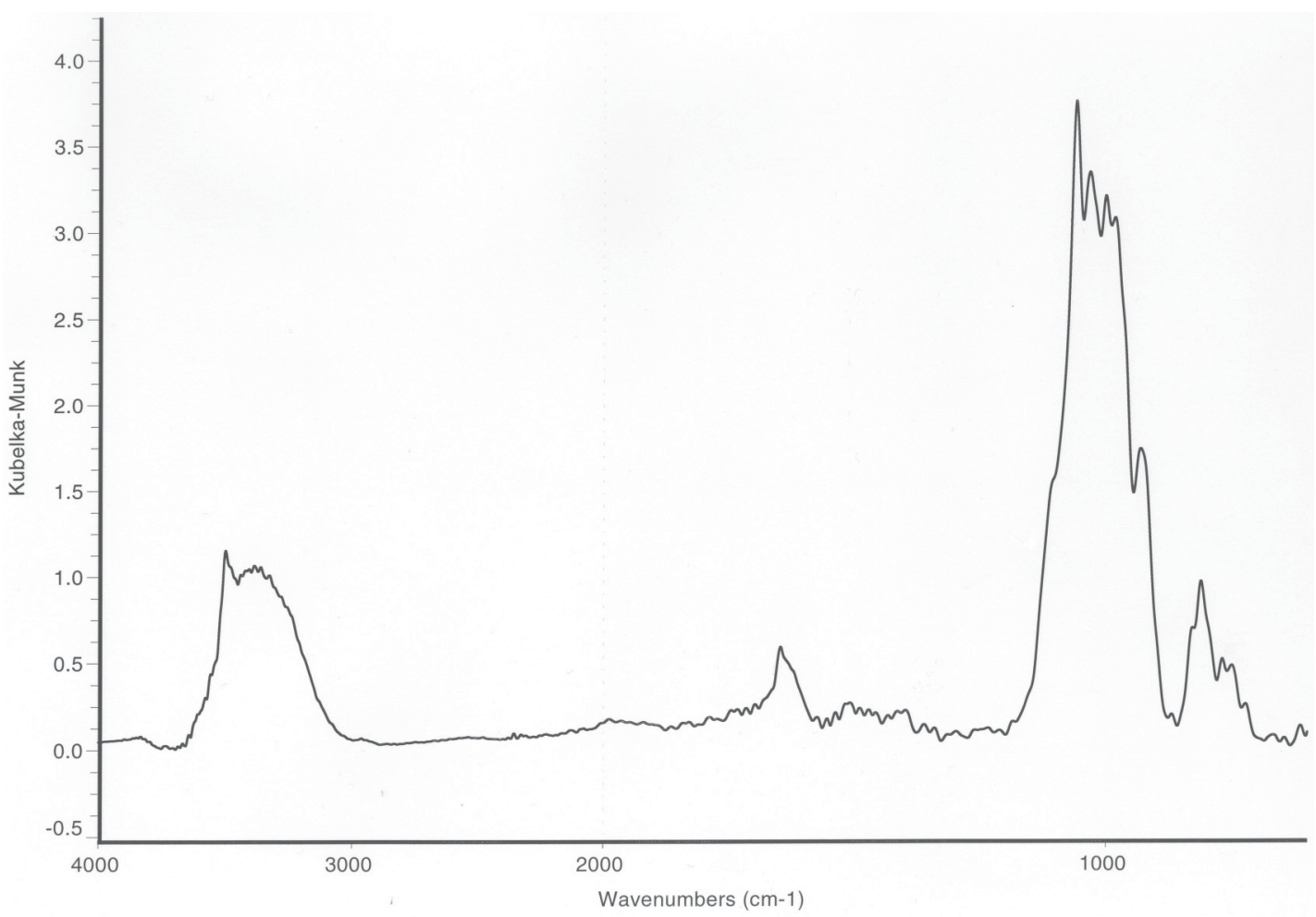

FIG. 3. The infrared-absorption spectrum of calciopetersite from Domašov nad Bystřicí. A digital version of this spectrum is available from the Depository of Unpublished Data, CISTI, National Research Council of Canada, Ottawa, Ontario K1A 0S2, Canada.

Farmer (1974), Sejkora et al. (1999) and Martens \& Frost (2003).

Bands in the range $3800-2900 \mathrm{~cm}^{-1}$ were assigned to the $v \mathrm{OH}$ stretching vibrations in $\mathrm{H}_{2} \mathrm{O}$ molecules (broad bands at 3390 and $3326 \mathrm{~cm}^{-1}$ ) and hydroxyl groups (sharp band at $3501 \mathrm{~cm}^{-1}$ ) in the structure of calciopetersite, and those in the range $1700-1550 \mathrm{~cm}^{-1}$ to the $\delta \mathrm{H}-\mathrm{O}-\mathrm{H}$ bending vibrations of $\mathrm{H}_{2} \mathrm{O}$ molecules.

The existence of more bands and shoulders in both regions of the infrared spectrum indicates that several structurally nonequivalent hydroxyl groups and $\mathrm{H}_{2} \mathrm{O}$ groups, bonded with different hydrogen bonds, are present in the structure. Approximate O-H...O hydrogen bond lengths are $\sim 2.7, \sim 2.79-2.8$ and $\sim 2.9 \AA$ (Libowitzky 1999). Some $\mathrm{H}_{2} \mathrm{O}$ groups may well have a zeolitic character, as proposed by Zemann (1991) and Miletich \& Zemann (1993) for other members of this group. The presence of zeolitic $\mathrm{H}_{2} \mathrm{O}$ in agardite was also reported by Dietrich et al. (1969) on the basis of a thermal analysis. The crystal structure of Ca-rich agardite (Aruga $\&$ Nakai 1985) consists of infinite chains of $\mathrm{CuO}_{4}$ groups running along the $c$ axis, which are alternately connected to $\mathrm{MO}_{9}$ polyhedra and $\mathrm{XO}_{4}$ tetrahedra. The charge compensation required by the substitution of a divalent cation $\left(\mathrm{Ca}^{2+}\right)$ for a trivalent cation (e.g., $\mathrm{Bi}^{3+}$, $\mathrm{REE}^{3+}$ ) is assured by the concomitant substitution of $(\mathrm{OH})^{-}$for $\mathrm{O}^{2-}$. The square-planar $\mathrm{CuO}_{4}$ groups share a pair of the opposite edges to form chains along $a$ axis. The $M \mathrm{O}_{9}$ polyhedra and the $\mathrm{XO}_{4}$ tetrahedra alternately stack parallel to the $c$ axis and join the $\mathrm{CuO}_{4}$ chains. The large temperature-factor of one of the oxygen atoms (Aruga \& Nakai 1985) confirms the zeolitic nature of the $\mathrm{H}_{2} \mathrm{O}$ molecules.

The $\left(\mathrm{XO}_{4}\right)^{3-}$ tetrahedron in the structure of mixitegroup minerals is distorted, and its point symmetry is lower than $\mathrm{T}_{\mathrm{d}}$ (Sejkora et al. 1999). Thefore, all vibrations $\left(v_{1}, v_{3}\right.$ in our data range) become active in the infrared spectrum, and the triply degenerate $\nu_{3}$ vibration is split. At least six bands in the region $1200-950 \mathrm{~cm}^{-1}$ were assigned to the triply degenerate antisymmetric stretching vibration $\nu_{3}\left(\mathrm{PO}_{4}\right)^{3-}$, and a band at $933 \mathrm{~cm}^{-1}$ with shoulder at $924 \mathrm{~cm}^{-1}$, to the symmetric stretching vibration $v_{1}\left(\mathrm{PO}_{4}\right)^{3-}$. The six bands assigned to the $v_{3}$ and two bands to the $\nu_{1}$ vibrations of $\left(\mathrm{PO}_{4}\right)^{3-}$ indicate the presence of at least two structurally nonequivalent phosphate groups in calciopetersite. 
The presence of a $\left(\mathrm{PO}_{3} \mathrm{OH}\right)$ group in the structure can be inferred from the study of its infrared spectra (Keller 1971). The in-plane $\delta(\mathrm{P}-\mathrm{OH})$ vibrations were observed in the range $1550-1200 \mathrm{~cm}^{-1}$, with weak maxima at 1498 and $1379 \mathrm{~cm}^{-1}$; some coincidences with overtones and combination bands are possible. The bands in the range $850-700 \mathrm{~cm}^{-1}$ (with maxima at $829,811,770,750$ and $722 \mathrm{~cm}^{-1}$ ) can be related to the out-of-plane bending vibration $\delta(\mathrm{P}-\mathrm{OH})$. In this range, some coincidences with libration modes of molecular $\mathrm{H}_{2} \mathrm{O}$ and some $M-\mathrm{OH}$ vibrations cannot be excluded.

\section{CONCLUDing REMARKS}

Calciopetersite is the Ca- and $\mathrm{P}$-dominant member of the mixite group. Calcium is dominantly incorpo- rated at the $M$ site $(0.58 a p f u)$ of the general formula $M \mathrm{Cu}_{6}\left(\mathrm{XO}_{4}\right)_{3}(\mathrm{OH})_{6} \cdot 3 \mathrm{H}_{2} \mathrm{O}$; however, part of the $\mathrm{Ca}(0.14$ apfu) is very likely present at the $\mathrm{Cu}$ site as well.

An identification of individual members of the mixite group merely on the basis of their X-ray powderdiffraction patterns and calculated unit-cell parameters is ambiguous owing to extensive substitutions at the $M$ and $X$ site, respectively, resulting in competing influences on their unit-cell parameters (Table 4). A quantitative chemical analysis is necessary for a correct determination of the mineral phases.

Calciopetersite represents a rare product of the leaching of chalcopyrite and other copper sulfides in an oxidizing and hydrous environment at a low temperature during weathering processes. The individual elements forming calciopetersite were derived from chalcopyrite,

TABLE 4. COMPARISON OF MINERAL PHASES IN THE MIXITE GROUP

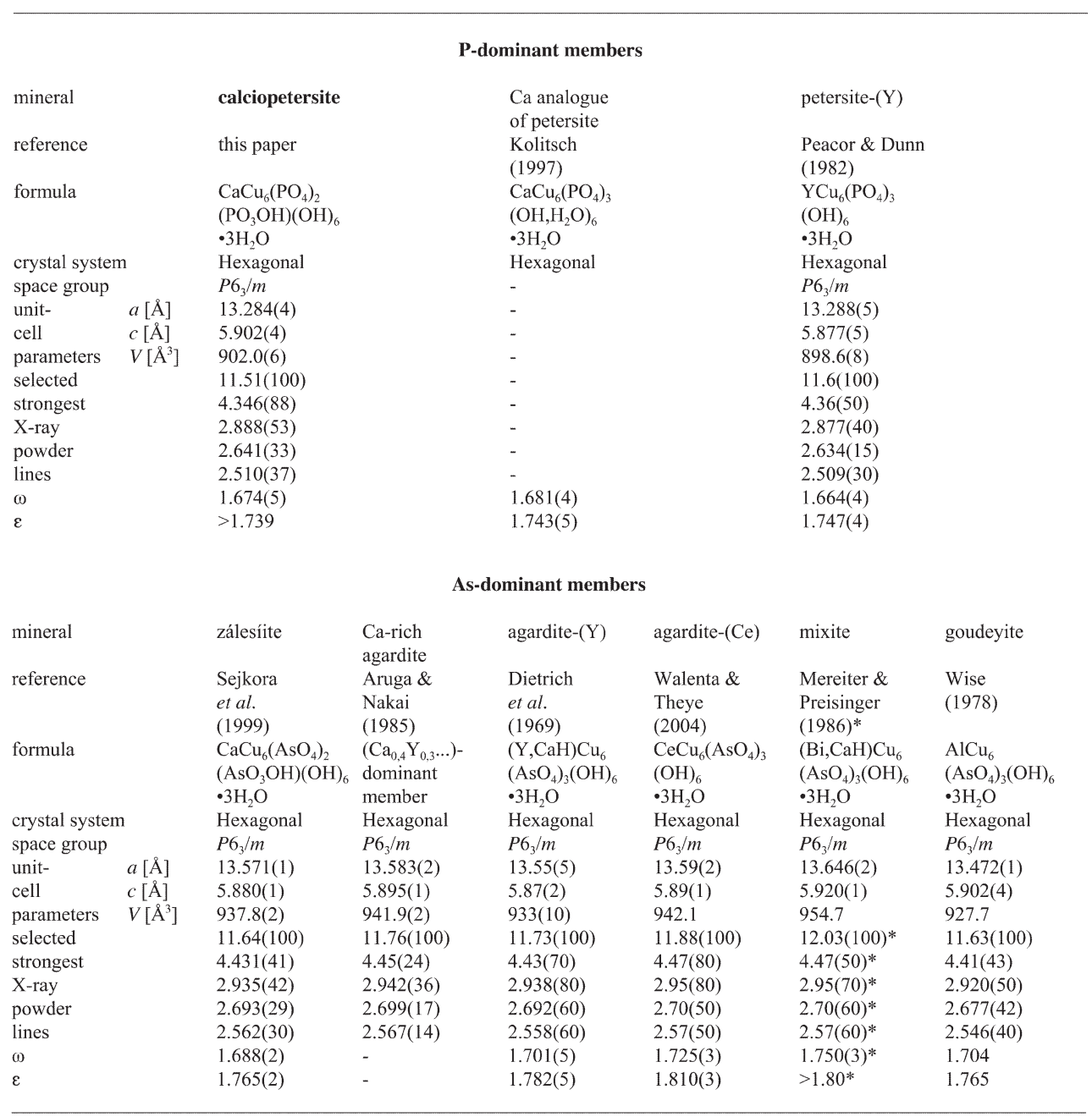

* See also Walenta (1960). 
chalcocite and covellite $(\mathrm{Cu})$, the host graywackes $(\mathrm{Ca}, \mathrm{P})$, and associated carbonate veins (Ca, Y, REE) containing the REE mineral calkinsite-(Ce) (Zimák \& Novotný 2002).

\section{ACKNOWLEDGEMENTS}

The authors thank to Miroslava Novotná (Institute of Chemical Technology, Prague), Jiří Čejka (National Museum, Prague) and Ivan Němec (Faculty of Science, Charles University, Prague) for their support of this study. This work was supported by grants MK00002327201 and 205/03/D004 to JS, MSM0021622412 to MN, and IRSM 340.410 to VŠ.

\section{REFERENCES}

AlBerTinI, C. (1994): Mineralogische Seltenheiten vom Monte Cervadone (Alpe Devero/Italien - Binntal/Schweiz). Mineralien Welt 5, 2, 18-32.

ARUGA, A. \& NAKAI, I. (1985): Structure of Ca-rich agardite, $\left(\mathrm{Ca}_{0.40} \mathrm{Y}_{0.31} \mathrm{Fe}_{0.09} \mathrm{Ce}_{0.06} \mathrm{La}_{0.04} \mathrm{Nd}_{0.01}\right) \mathrm{Cu}_{6.19}\left[\left(\mathrm{AsO}_{4}\right)_{2.42}\right.$ $\left.\left(\mathrm{HAsO}_{4}\right)_{0.49}\right](\mathrm{OH})_{6.38} \cdot 3 \mathrm{H}_{2} \mathrm{O}$. Acta Crystallogr. C41, $161-$ 163.

BuRnham, C.W. (1962): Lattice constant refinement. Carnegie Inst. Wash., Yearb. 61, 132-135.

Dietrich, J.E., Orliac, M. \& Permingeat, F. (1969): L'agardite, une nouvelle espèce minérale, et le problème du chlorotile. Bull. Soc. fr. Minéral. Cristallogr. 92, 420434

DRAKe, M.J. \& WeILL, D.F. (1972): New rare earth elements standards for electron microprobe analysis. Chem. Geol. 10, 179-181.

Duncumb, P. \& Reed, S.J.B. (1968): The calculation of stopping power and backscatter effects in electron probe microanalysis. In Quantitative Electron Probe Microanalysis (K.F.J. Heinrich, ed..). Nat. Bur. Standards, Spec. Publ. 298, $133-154$

FARMER, V.C., ed. (1974): The infrared spectra of minerals. Mineral. Soc., Monogr. 4.

Keller, P. (1971): Die Kristallchemie der Phosphat- und Arsenatminerale unter besonderer Berücksichtigung der Kationen-Koordinationspolyeder und des Kristallwassers. I. Die Anionen der Phosphat- und Arsenatminerale. Neues Jahrb. Mineral., Monatsh., 491-510.

Kolitsch, U. (1997a): Neufunde von Mineralien aus einigen Vorkommen der Vogesen, Frankreich: Triembach, Bluttenberg und Val d’Ajol. Aufschluss 48, 2, 65-91.

(1997b): Das Ca-Analogon von Petersit und einige weitere Neufunde aus dem sächsisch-böhmischen Erzgebirge und dem Vogtland. Mineralien Welt 8, 4, 17-20.

LiBOwITZKY, E. (1999): Correlation of OH stretching frequencies and $\mathrm{O}-\mathrm{H} . . . \mathrm{O}$ hydrogen bond lengths in minerals. Monatsh. Chem. 130, 1047-1059.

Martens, W. \& Frost, R. L. (2003): An infrared spectroscopic study of the basic copper phosphate minerals: cornetite, libethenite, and pseudomalachite. Am. Mineral. 88, 37-46.

Mereiter, K. \& Preisinger, A. (1986): Kristallstrukturdaten der Wismutminerale Atelestit, Mixit und Pucherit. Öst. Akad. Wissen., math. - naturwiss. Kl. 123, 79-81.

Miletich, R. \& Zemann, J. (1993): Die Synthese des Minerals Mixit. Aufschluss 44, 17-21.

Olmi, F., Sabelli, C. \& Trosti Ferroni, R. (1991): A contribution to the crystal chemistry of mixite group minerals from Sardinia (Italy). Neues Jahrb. Mineral., Monatsh., 487-499.

ONDRUS, P. (1995): ZDS - software for analysis of X-ray powder diffraction patterns. Version 6.01. User's guide.

PeAcor, D.R. \& DunN, P.J. (1982): Petersite, a REE and phosphate analog of mixite. Am. Mineral. 67, 1039-1042.

PhiliberT, J.A. (1963): A method for calculation of the absorption correction in electron probe microanalysis. In X-ray Optics and X-Ray Microanalysis (V.E. Coslet \& A. Engstrom, eds.). Academic Press. New York, N.Y.

SCHRAUf, A. (1880): Ueber Arsenate von Joachimsthal. 1. Mixit, ein neues Kupferwismuthydroarsenat. Z. Krystallogr. Mineral. 4, 277-281.

SEJKora, J., RídKoŠIL, T. \& ŠRein, V. (1999): Zálesíite, a new mineral of the mixite group, from Zálesí, Rychlebské hory Mts., Czech Republic. Neues Jahrb. Mineral., Abh. 175, 105-124.

\& ŠREIN, V. (1996): A contribution to the crystal chemistry of mixite from occurrences in Czech Massif Zprávy o geol. výzk. vr. 1995, 153-155 (in Czech).

Walenta, K. (1960): Chlorotil und Mixit. Neues Jahrb. Min eral., Monatsh., 223-236.

(1992): Die Mineralien des Schwarzwaldes und ihre Fundstellen. C. Weise Verlag, Munich, Germany.

(2003): Mineralien der Mixitgruppe aus dem Schwarzwald. Erzgräber 17, 46-51.

\& Theye, T. (2004): Agardit-(Ce) von der Grube Clara im mittleren Schwarzwald. Aufschluss 55, 17-23.

WISE, W. S. (1978): Parnauite and goudeyite, two new copper arsenate minerals from the Majuba Hill mine, Pershing County, Nevada. Am. Mineral. 63, 704-708.

Zemann, J. (1991): Nichtsilikatische Zeolithe. Mitt. Österr. Mineral. Ges. 136, 21-34.

ZiMÁK, J. \& NovotNÝ, P. (2002): REE- minerals from hydrothermal veins in Lower Carboniferous sediments of the Nízký Jeseník and Oderské vrchy Uplands. Čas. Slez. Muz. Oprava (A) 51, 179-182 (in Czech).

\& DobEŠ, P. (2005): Hydrothermal mineralization near Domašov nad Bystřicí, the Nízký Jeseník Mts. Věstník Čes. geol. Úst. (in press; in Czech).

Received May 28, 2004, revised manuscript accepted May 8, 2005 